\title{
İyi Tarım Uygulamalarının Mandarin Üretiminde Enerji Kullanım Etkinliği ve Ekonomik Analiz Üzerine Etkisi: İzmir İli Örneği
}

\author{
Selçuk KARABAT ${ }^{1 *} \quad$ Bașak AYDIN² \\ 'Bağcllık Araștırma Enstitüsü Müdürlüğü, Manisa \\ ${ }^{2}$ Atatürk Toprak Su ve Tarımsal Meteoroloji Araștırma Enstitüsü Müdürlüğü, Kırklareli
}

\begin{abstract}
*Sorumlu yazar e-mail (Corresponding author e-mail): selcuk.karabat@tarim.gov.tr
Geliș tarihi (Received) : 21.06.2017

Kabul tarihi (Accepted): 03.07.2017

DOI : 10.21657/topraksu.410087
\end{abstract}

\section{Öz}

Bu çalıșma, İzmir ilinde İyi Tarım Uygulamaları yapan ve yapmayan mandarin üreten tarım ișletmelerini kapsamaktadır. Çalıșmanın temel amacı, İyi Tarım Uygulamaları yapan ve yapmayan ișletmelerde mandarin üretiminde enerji kullanım etkinliğinin belirlenmesi ve ekonomik olarak karșılaștırılmasıdır. İzmir ilinde İyi Tarım Uygulamaları yapan 20 mandarin üreticisinin tamamıyla, aynı sayıda İyi Tarım Uygulamaları yapmayan mandarin üreticisi ile anket çalıșması yapıımıștır. Değerlendirme sonuçlarına göre İyi Tarım Uygulamaları yapan ișletmelerde enerji çıktı/girdi oranı 2.24 enerji verimliliği 0.93 $\mathrm{kg} \mathrm{MJ}^{-1}$, spesifik enerji $1.07 \mathrm{MJ} \mathrm{kg}^{-1}$ ve net enerji 58925.62 MJ ha-1 olarak hesaplanmıștır. İyi Tarım Uygulamaları yapmayan ișletmelerde ise enerji çıtı/girdi oranı 2.04, enerji verimliliği $0.85 \mathrm{~kg} \mathrm{MJ}^{-1}$, spesifik enerji $1.17 \mathrm{MJ} \mathrm{kg}^{-1}$ ve net enerji $56301.02 \mathrm{MJ} \mathrm{ha}^{-1}$ olarak hesaplanmıștır. İzmir ilinde İyi Tarım Uygulamaları yapan ișletmelerde $1 \mathrm{~kg}$ mandarin yetiștirmenin maliyeti $0.52 \mathrm{TL}$, İyi Tarım Uygulamaları yapmayan ișletmelerde 0.47 TL olarak belirlenmiștir. İyi Tarım Uygulamaları yapan ișletmelerde nispi kâr 1.24 olarak, İyi Tarım Uygulamaları yapmayan ișletmelerde ise 1.19 olarak belirlenmiștir. Enerji çıktı/ girdi analizi ve ekonomik analiz sonuçlarına göre, İyi Tarım Uygulamaları yapan ișletmelerde mandarin yetiștiriciliğinin daha avantajlı olduğu belirlenmiștir.

Anahtar Kelimeler: Ekonomik Analiz, Enerji Analizi, İyi Tarım Uygulamaları, İzmir

\section{Effect of Good Agricultural Practices on Energy Use Efficiency and Economic Analysis in Mandarin Farming: Case of İzmir Province}

\begin{abstract}
This study includes the mandarin farms which perform and do not perform good agricultural practices in İzmir province. The basic purpose of this study is the determination of energy use efficiency and economical comparison of the farms performing and not performing good agricultural practices. The 20 mandarin producers who applied good agricultural practices were interviewed and data were gathered by using questionnaire method in İmir province. In the same provinces, the same survey was also conducted with the same number of producers which did not perform good agricultural practices. According to the results, energy output/input ratio, energy productivity, specific energy and net energy were determined to be respectively as $2.24,0.93 \mathrm{~kg} \mathrm{MJ}^{-1}, 1.07 \mathrm{MJ} \mathrm{kg}{ }^{-1}$ and 58925.62 $\mathrm{MJ} \mathrm{ha}^{-1}$ in the enterprises performing good agricultural practices. Energy output/input ratio, energy productivity, specific energy and net energy were determined to be respectively as $2.04,0.85 \mathrm{~kg} \mathrm{MJ}^{-1}$,
\end{abstract}


1.17 $\mathrm{MJ} \mathrm{kg}^{-1}$ and $56301.02 \mathrm{MJ} \mathrm{ha}^{-1}$ in the enterprises not performing good agricultural practices. In Izmir province the cost of producing; one $\mathrm{kg}$ of mandarin was calculated as $0.52 \mathrm{TL}$ in the enterprises which applied good agriculture while it was calculated as $0.47 \mathrm{TL}$ at the enterprises which did not perform the good agriculture. Relative profit was determined to be respectively as 1.24 in the enterprises performing good agricultural practices and 1.19 in the enterprises not performing good agricultural practices. According to energy output/input analysis and economic analysis results, mandarin farming was determined to be more advantageous in the enterprises performing good agricultural practices.

Key words: Economic Analysis, Energy Analysis, Good Agricultural Practices, İzmir

\section{Giriș}

Kökeni Güneydoğu Asya olan turunçgillerin çağdaș anlamda üretimi 19. yüzyılda $A B D$ 'de bașlamıș ve hızla yayılmıștır. Turunçgiller dünyada en çok yetiștirilen ve tüketilen meyve grubudur. Turunçgiller (narenciye); portakal, limon, mandarin ve greyfurt (altıntop) gibi "Citrus" cinsine ilișkin türleri içermektedir. Bu bitkilerin meyvelerinden gıda olarak yararlanıldığı gibi kabuklarından, yapraklarından ya da çiçeklerinden parfümeride koku vermekte kullanılan uçucu yağlar da elde edilmektedir.

Türkiye'de turunçgil yetiștiriciliği Cumhuriyet'ten sonra hızla gelișmiștir. Türkiye turunçgil yetiștiriciliği için ekolojik koșullar açısından oldukça uygundur. Yetiștirilen çeșitlerin büyük bir kısmı Italya üzerinden gelmiștir. Türkiye, dünya turunçgil üretim alanının en kuzey sınırındadır. Bu nedenle, turunçgil yetișen tüm bölgelerde zaman zaman dondurucu düșük sıcaklık zararları görülmektedir. Bu nedenle bahçeler don tutmayan ya da çok az don tutan yörelerde kurulmall; bahçelerin soğuk hava ve rüzgârlara açık yönlerde olmamasına dikkat edilmelidir (Anonim, 2017a).

Mandarin (Citrus reticulata); IIman iklime sahip bütün ülkelerde kültür șekilleri yetiștirilen, yaprak dökmeyen, uçucu yağ tașıyan bu küçük ağaçların meyveleri Türkiye'de çok sevilir. Ege, Akdeniz ve Doğu Karadeniz Bölgeleri'nde bol miktarda üretilmektedir. Narenciye üretiminin yaklașık \%25'ini teșkil eder. Tatlı, kokulu, lezzetli, vitamince zengin bir meyvedir. Ticari olarak yetiștiriciliği yapılan turunçgil türleri içerisinde düșük sıcaklıklara en dayanıklısı buna karșilık meyveleri düșük sıcaklıklara en hassas olanıdır. Mandarin çeșitlerinin olgunluk dönemleri aylara yayılmıs durumdadır. Meyve kabuk renkleri açık sarıdan koyu kırmızıya kadar çeșitlilik intiva eder.

Türkiye'de 2014-2015 üretim sezonunda 1.047.000 ton mandarin üretimi gerçekleșmiș olup, üretimin \%79’u Akdeniz, \%19’u Ege Bölgesi'nden karșılanmaktadır. İlere göre mandarin üretimine bakıldığında ise, Hatay'ın (\%33) Türkiye mandarin üretiminde ilk sırada yer aldığı, Adana (\%27) ve İzmir (\%14) illerinin ise ikinci ve üçüncü sırayı aldığı görülmektedir. En fazla üretilen mandarin çeșidi yaklașık 644000 ton üretim miktarı ile Satsuma çeșidi olmuștur (Aygören, 2016).

Gelișen gıda teknolojisi ve tüketici bilinçlenmesi günümüzde ürün kalitesini iyileștirme gayretlerini de arttırmaktadır. Tüketicilerin yașamları için temel gereksinimleri olan gıdaların, güncel teknolojik gerekler doğrultusunda üretilmesi, sağlıklı beslenmenin sağlanması yolunda önemli bir hizmettir. Gıda güvenliğinin ve kalite güvencesinin sağlanması çabaları da tüketici ve toplum sağlığı açısından büyük önem tașımaktadır. İyi Tarım Uygulamaları FAO tarafından, "tarımsal üretim sisteminin sosyal açıdan yașanabilir, ekonomik açıdan karlı ve verimli, insan sağlığını koruyan, hayvan sağlık ve refahı ile çevreye önem veren bir hale getirmek için uygulanması gereken ișlemler" olarak tanımlanmaktadır. İyi Tarım Uygulamaları konusundaki gelișmeler, Türkiye'de toplam tarımsal üretim ve inracat miktarlarının iç ve dıș pazarda rekabet edecek seviyeye ulașmasında önemli rol oynayacaktır. Bu sayede dıș pazara kaliteli güvenli ürün sunulurken, iç pazarda tüketicilerin sağlıklı ve güvenilir ürün tüketmeleri sağlanmıș olacaktır (Anonim, 2017b).

Mandarin denilince İzmir'in Seferihisar ilçesi kaliteli ve sağlıklı üretimiyle dikkati çekmektedir. Mandarin üretimi çok uzun yıllardır Seferihisar ilçesinde yapılmakta ve son yıllarda üreticilerin önemli bir kesimi l̇yi Tarım Uygulamaları çerçevesinde firmalarla anlașmalı olarak üretim yapmaktadırlar. İyi Tarım Uygulamaları́nın artıș göstermesi ve mandarin üretiminin yüksek seviyelere çımıș olması, araștırma alanı olan Seferihisar ilçesinde bu tür bir çalıșmanın yürütülmesinde etkili olmuștur. 
Tarımsal üretim ișlemlerinde kullanılan girdilerin toplam enerji değerinin, elde edilen ürünün enerji değeri ile karșılaștırılması, üretim verimliliğinin değerlendirilmesi için daha gerçekçi bir yaklașımdır (Öztürk, 2011). Enerji çıktı/girdi analizleri ile enerjinin ne kadar etkin kullanılıp kullanılmadığı, böylece tarımın sürdürülebilir hale gelmesi, fosil yakıtların kullanılmasının azaltılması, çevrenin korunması ve ekonomik faydanın sağlanması için tarımsal üretimde etkin enerji kullanımı önemlidir (Bilgili, 2012). Üreticiler üretim alanlarını büyütmeden, daha fazla girdi kullanarak üretim miktarlarını arttırmaya çalıșmaktadırlar. Aynı zamanda üreticiler alternatif ve etkili enerji girdi kullanımı bakımından yeterli bilgiye sahip değildirler (Yılmaz vd., 2005). Bu durum üretim maliyetlerini de olumsuz yönde etkilemektedir.

Bu çalıșmada İyi Tarım Uygulamaları yapan ve yapmayan tarım ișletmelerinde mandarin üretiminde kullanılan girdilerin ve bu girdilerin enerji eșdeğerlerinin bulunması amaçlanmıștır. Karșılaștırmalı enerji çıtı/girdi analizi yapıımıș olup kullanılan girdilerin etkinlik dereceleri de belirlenmiștir. Çalıșmada ayrıca İyi Tarım Uygulamaları yapan ve yapmayan ișletmelerde mandarin üretiminin ekonomik analizi yapılmıș ve elde edilen sonuçlar doğrultusunda öneriler geliștirilmiștir.

\section{Materyal ve Yöntem \\ Materyal}

Çalıșmanın ana materyalini İzmir ilinde mandarin üretiminde iyi tarım uygulayan ve uygulamayan üreticilerle yapılan anket çalıșmaları olușturmuștur. Bununla birlikte araștırma konusuyla ilgili olarak daha önce yapılmıș olan yerli ve yabancı çalıșmalar ile istatistiklerden de yararlanılmıștır.

\section{Yöntem}

Çalıșmada, İzmir ilinde Tam Sayım Yöntemi'ne göre, İyi Tarım Uygulaması yapan 20 mandarin üreticisinin tamamıyla anket çalıșması yapılmıștır. Ayrıca, karșılaștırma yapilması açısından, aynı sayıda İyi Tarım Uygulaması yapmayan üretici ile anket çalıșması yapılması da öngörülmüștür.

Enerji çıktı/girdi analizinin belirlenmesi için mandarin üretiminde kullanılan girdilerin ve üretimden elde edilen çıtının miktarları bulunmuștur. Bu veriler enerji eșdeğeri katsayıları ile çarpılmıștır (Çizelge 1).

Çizelge 1. Tarımsal üretimde girdi ve çıktıların enerji eșdeğerleri

Table 1. Energy equivalents of the inputs and outputs in agricultural production

\begin{tabular}{|c|c|c|}
\hline & Enerji eșdeğeri katsayısı (MJ birim-1) & Kaynaklar \\
\hline \multicolumn{3}{|l|}{ Girdiler } \\
\hline İșgücü (h) & 1.96 & (De ve ark. 2001; Singh 2002) \\
\hline Makine gücü (h) & 64.80 & (Singh, 2002; Baran ve ark. 2016) \\
\hline \multicolumn{3}{|l|}{ Kimyasallar (kg) } \\
\hline Böcek ilaçları & 101.20 & (Yaldız ve ark. 1993; Rafiee ve ark. 2010) \\
\hline Mantar ilaçları & 216.00 & (Rafiee ve ark. 2010) \\
\hline Ot ilaçları & 238.00 & (Rafiee ve ark. 2010) \\
\hline \multicolumn{3}{|l|}{ Gübreler (kg) } \\
\hline Azot & 60.60 & (Singh 2002) \\
\hline Fosfor & 11.15 & (Singh 2002) \\
\hline Potasyum & 6.70 & (Singh 2002) \\
\hline Sülfat & 1.12 & (Mohammadi ve ark. 2010) \\
\hline Çiftlik gübresi (kg) & 0.30 & (De ve ark. 2001; Singh 2002) \\
\hline Yakıt (I) & 56.31 & (De ve ark. 2001; Singh 2002) \\
\hline Elektrik (kWh) & 3.60 & (Özkan ve ark. 2004) \\
\hline Sulama suyu $\left(\mathrm{m}^{3}\right)$ & 0.63 & (Yaldız ve ark. 1993; Baran ve ark. 2017) \\
\hline \multicolumn{3}{|l|}{ Çıktı } \\
\hline Verim $(\mathrm{kg})$ & 2.40 & (Strapatsa ve ark. 2006) \\
\hline
\end{tabular}


Mandarin üretiminde enerji çıtı/girdi analizini belirlemek amacıyla așağıdaki formüller kullanılmıștır (Mandal vd., 2002).

Enerji $\frac{\text { çıktı }}{\text { girdi }}$ oranı $=\frac{\left(\text { Enerji çıktısı }\left(\mathrm{MJ} \mathrm{ha}^{-1}\right)\right.}{\left(\text { Enerji girdisi }\left(\mathrm{MJ} \mathrm{ha}^{-1}\right)\right.}$

Enerji verimliliği $=\frac{\text { Mandarin üretim miktarı }\left(\mathrm{kg} \mathrm{ha}^{-1}\right)}{\left(\text { Enerji girdisi }\left(\mathrm{MJ} \mathrm{ha}^{-1}\right)\right.}$

Spesifik enerji $=\frac{\text { Enerji girdisi }(\mathrm{MJ} \text { ha-1 }}{\text { Mandarin üretim miktarı }\left(\mathrm{kg} \mathrm{ha}^{-1}\right)}$

Net enerji= Enerji çıtısı (MJ ha'-1)- Enerji girdisi (MJ ha-1)

Mandarin üretiminde kullanılan enerji girdileri farklı enerji normlarına göre incelenmiștir. Doğrudan enerji ișgücü, yakıt, su ve elektrik gücünü; dolaylı enerji, gübreler, kimyasal ilaçlar, çeki gücü ve tohumu kapsamaktadır. Yenilenebilir enerji kaynakları ișgücü, tohum ve su; yenilenemeyen enerji kaynakları yakıt, gübreler, kimyasal ilaçlar, çeki gücü ve elektrik gücünü kapsamaktadır (Yılmaz vd., 2010).

İșletme giderleri bütçe analiz yöntemi, üretim giderleri alternatif maliyet unsuru yöntemi ile saptanmıștır. İyi Tarım Uygulamaları yapılarak ve yapılmayarak yetiștirilen mandarinin maliyetleri, brüt kâr, net kâr ve nispi kâr belirlenerek ekonomik anlamda karșılaștırması yapılmıștır. Mandarin üretiminin ekonomik analizinde așağıdaki formüller kullanılmıștır (Açıl ve Demirci, 1984; Kıral vd., 1999; Tanrıvermiș, 2000).

Brüt kâr=Gayrisafi üretim değeri-değișken masraflar

Mutlak (net) kâr=Gayrisafi üretim değeri-üretim masrafları

Nispi (oransa) kâr=Gayrisafi üretim değeri/üretim masrafları

Değișken masrafların bir üretim dönemine yayılması nedeniyle değișken masraflar toplamının yarısı alınarak bitkisel üretime uygulanan kredi faiz oranıyla çarpılması ile döner sermaye faizi hesaplanır. Çıplak arazi değerinin faizi, araștırma bölgesindekiçıplak arazinin carialım satım değerinin $\% 5^{\prime i}$ alınarak tespit edilmiștir (Kıral vd., 1999). Tesis sermayesi faizi ise toplam tesis masrafları yarı değerine \%5 faiz uygulanarak hesaplanmıștır. Tesis masrafları toplamının bahçenin ekonomik ömrüne bölünmesiyle, tesis masrafları amortisman payı bulunmuștur. Bu dönemde her yıl yapılan masrafların toplamına, o yıl gerçekleșen masrafları \%5'i normal faiz gideri olarak eklenmiștir. Genel idari giderlerinin hesaplanmasında ise değișken masraf toplamının \%3'ü alınmıștır (Açıl ve Demirci, 1984). İyi Tarım Uygulamaları yapılan mandarin üretiminde sertifikasyon ücreti ve analiz ücretleri değișken masraf olarak alınmıștır. İyi Tarım Uygulamaları için üretim alanında yapılması zorunlu ilaç deposu, ilaç dolabı, yangın söndürme ekipmanları, maske, gözlük eldiven, palet, metal varil, ilaç hazırlama ünitesi, ilk yardım kutusu, tuvalet için yıllık amortisman oranları hesaplanarak, sabit masraflar kısmında tesis masrafları amortisman payına ilave edilmiștir.

\section{Bulgular ve Tartıșma}

\section{Mandarin Üretiminde Girdi Kullanımı}

İșletmelerin mandarin üretiminde kullandıkları girdi miktarları Çizelge 2'de verilmiștir. Araștırma bölgesinde lyi Tarım Uygulamaları yapan ișletmelerde mandarin üretiminde insan ișgücü gereksinimi hektara 756.5 saat olarak belirlenmiștir. Toplam ișgücü içerisinde en yüksek payı hektara 370 saat ile hasat ișlemi olușturmaktadır. Mandarin üretiminde budama ișlemi hektara 160 saat, çapalama ișlemi 70 saat, gübreleme ișlemi 44 saat, sulama ișlemi 36 saat, gövde boyama ișlemi 25 saat, ilaçlama ișlemi 24 saat, tașıma ișlemi 20 saat, ara sürüm ișlemi 7.5 saat insan ișgücü gereksinimine sahiptir. İyi Tarım Uygulamaları yapan ișletmelerin mandarin üretiminde ortalama 5 kez gübreleme, 3 kez ilaçlama yaptığı görülmektedir. Bitki besin elementine göre kimyasal gübre kullanımı incelenmiș ve hektara $317.25 \mathrm{~kg}$ azot, $364.5 \mathrm{~kg}$ fosfor, $331.5 \mathrm{~kg}$ potasyum ve $120 \mathrm{~kg}$ sülfat olmak üzere toplam 1133.25 kg gübre kullanıldığı tespit edilmiștir. İncelenen ișletmelerde etken madde olarak hektara 34.4 kg kimyasal ilaç kullanıldığı ve bu ilaçların $10.5 \mathrm{~kg}$ insektisit, $11.5 \mathrm{~kg}$ fungusit ve $12.4 \mathrm{~kg}$ herbisit olduğu belirlenmiștir. Mandarin üretiminde kullanılan diğer önemli girdiler ise çiftlik gübresi, makine gücü, yakıt, elektrik ve sulama suyudur. İyi Tarım Uygulamaları yapan ișletmelerde hektara çiftlik gübresi kullanımı 3400 kg, makine kullanımı 44 saat, yakıt tüketimi 66 I, elektrik tüketimi $1015 \mathrm{~kW}$, sulama suyu tüketimi ise $4240 \mathrm{~m}^{3}$ olarak hesaplanmıștır.

İyi Tarım Uygulamaları yapmayan ișletmelerde insan ișgücü gereksinimi 762 saat olarak belirlenmiștir. Hasat ișlemi hektara 370 saat, budama ișlemi 160 saat, çapalama ișlemi 75 
Çizelge 2. Mandarin üretiminde kullanılan girdi ve çıktı miktarları

Table 2. Input and output amounts in mandarin production

\begin{tabular}{lcc}
\hline Girdiler & iTU yapan & ITU yapmayan \\
\hline İșücü (h) & 756.50 & 762.00 \\
\hline Makine gücü (h) & 44.00 & 45.00 \\
\hline Kimyasallar (kg) & 34.40 & 37.00 \\
Böcek ilaçları & 10.50 & 11.00 \\
Mantar ilaçları & 11.50 & 12.50 \\
Ot ilaçları & 12.40 & 13.50 \\
\hline Gübreler (kg) & 1133.25 & 1259.00 \\
Azot & 317.25 & 354.50 \\
Fosfor & 364.50 & 433.00 \\
Potasyum & 331.50 & 327.50 \\
Sülfat & 120.00 & 144.00 \\
\hline Ciftlik qübresi (kg) & 3400.00 & 3200.00 \\
\hline Yakıt (l) & 66.00 & 70.00 \\
\hline Elektrik (kWh) & 1015.00 & 1025.00 \\
\hline Sulama suyu $\left(\mathrm{m}^{3}\right)$ & 4240.00 & 4350.00 \\
\hline Çıtı & & 45950.00 \\
\hline Verim (kg) & 44360.00 & \\
\hline
\end{tabular}

saat, gübreleme ișlemi 40 saat, sulama ișlemi 40 saat, gövde boyama 30 saat, tașıma ișlemi 20 saat, ilaçlama ișlemi 19 saat, ara sürüm ișlemi 8 saat insan ișgücü gereksinimine sahiptir. İyi Tarım Uygulamaları yapmayan ișletmelerde mandarin üretiminde ortalama 5 kez gübreleme, 3 kez ilaçlama yapıldığı görülmektedir. Gübre kullanımının hektara $354.5 \mathrm{~kg}$ azot, $433 \mathrm{~kg}$ fosfor, $327.5 \mathrm{~kg}$ potasyum ve $144 \mathrm{~kg}$ sülfat olmak üzere toplam 1259 kg olduğu belirlenmiștir. İyi Tarım Uygulamaları yapmayan ișletmelerde hektara 37 kg kimyasal ilaç kullanıldığı ve bunun 11 kg insektisit, $12.5 \mathrm{~kg}$ fungusit ve $13.5 \mathrm{~kg}$ herbisit olduğu belirlenmiștir. Çiftlik gübresi kullanımı hektara 3200 kg, makine kullanımı 45 saat, yakıt tüketimi 70 I, elektrik tüketimi 1025 kW, sulama suyu tüketimi ise $4350 \mathrm{~m}^{3}$ olarak bulunmuștur.

Çıktı miktarları incelendiğinde İyi Tarım Uygulamaları yapan ișletmelerde hektara ortalama verim 44360 kg, İyi Tarım Uygulamaları yapmayan ișletmelerde ise $45950 \mathrm{~kg}$ olarak belirlenmiștir.

\section{Mandarin Üretiminin Enerji Analizi}

Mandarin üretiminde kullanılan girdilerin ve çıktının enerji eșdeğerleri Çizelge 3'te verilmiștir. Girdilerin enerji eșdeğerleri kullanılarak hesaplanan enerji girdisi İyi Tarım Uygulamaları yapan ișletmelerde 47538.38 MJ olarak bulunmuștur. Üretimde kullanılan tüm enerji kaynakları içinde en yüksek payı \%53.94 ile kimyasal gübreler almaktadır. Gübreler içerisinde ise \%40.44 ile azot ilk sıradadır. Kimyasal gübreleri \%13.67 ile kimyasal ilaçlar takip etmektedir. Illaçlar içerisinde \%6.20 ile ot ilaçları ilk sırayı almaktadır. Çizelge 3'te görüldüğü gibi yakıt, elektrik, makine kullanımı, sulama suyu, ișgücü ve çiftlik gübresi enerji kaynaklarının toplam enerji içindeki oranları sırasıyla \%7.82, \%7.69, \%6, $\% 5.62, \% 3.12$ ve \%2.14 olarak hesaplanmıștır.

İyi Tarım Uygulamaları yapmayan ișletmelerde ise mandarin üretiminde enerji girdisi 53978.98 MJ olarak bulunmuștur. Tüm enerji kaynakları içerisinde en yüksek payı \%60.48 ile kimyasal gübreler almaktadır. Gübreler içerisinde en yüksek payı \%43.44 ile azot almaktadır. Kimyasal ilaçların toplam enerji girdileri içerisindeki oranı ise \%10.35 olarak belirlenmiștir. Yakıt, elektrik, makine kullanımı, sulama suyu, ișgücü ve çiftlik gübresi enerji kaynaklarının toplam enerji içindeki oranları sırasılyla \%7.30, \%6.84, \%5.40, \%5.08, \%2.77 ve \%1.78 olarak hesaplanmıștır.

Özkan vd. (2004), Antalya yöresinde portakal, mandarin ve limon üretiminin enerji ve ekonomik analizini yapmıșlar ve mandarin üretiminde kullanılan toplam enerji girdisini 48838.17 MJ olarak bulmușlardır. Ayrıca, bu üç üründe de, enerji girdileri içinde en yüksek payı kimyasal gübrelerin aldığını (\%49.68) belirlemișlerdir. Namdari vd. (2011), İran'ın Mazandaran yöresinde turunçgil üretiminde enerji kullanımını incelemișler ve mandarin üretiminde toplam enerji girdisini 77501.17 MJ olarak bulmușlardır. Yakıtın enerji girdileri içerisinde en yüksek payı 
Çizelge 3. Mandarin üretiminde enerji kullanımı

Table 3. Energy usage in mandarin production

\begin{tabular}{|c|c|c|c|c|}
\hline \multirow[t]{2}{*}{ Girdiler } & \multicolumn{2}{|c|}{ İTU yapan } & \multicolumn{2}{|c|}{ iTU yapmayan } \\
\hline & Enerji eșdeğeri (MJ) & $\%$ & Enerji eșdeğeri (MJ) & $\%$ \\
\hline İșgücü (h) & 1482.74 & 3.12 & 1493.52 & 2.77 \\
\hline Makine gücü (h) & 2851.20 & 6.00 & 2916.00 & 5.40 \\
\hline Kimyasallar (kg) & 6497.80 & 13.67 & 5591.20 & 10.35 \\
\hline Böcek ilaçları & 1062.60 & 2.24 & 1113.20 & 2.06 \\
\hline Mantar ilaçları & 2484.00 & 5.23 & 1265.00 & 2.34 \\
\hline Ot ilaçları & 6497.80 & 6.20 & 3213.00 & 5.95 \\
\hline Gübreler (kg) & 25644.98 & 53.94 & 32646.06 & 60.48 \\
\hline Azot & 19225.35 & 40.44 & 23446.63 & 43.44 \\
\hline Fosfor & 4064.18 & 8.55 & 5386.52 & 9.98 \\
\hline Potasyum & 2221.05 & 4.67 & 3651.63 & 6.76 \\
\hline Sülfat & 134.40 & 0.28 & 161.28 & 0.30 \\
\hline Çiftlik gübresi (kg) & 1020.00 & 2.14 & 960.00 & 1.78 \\
\hline Yakıt (I) & 3716.46 & 7.82 & 3941.70 & 7.30 \\
\hline Elektrik (kWh) & 3654.00 & 7.69 & 3690.00 & 6.84 \\
\hline Sulama suyu $\left(\mathrm{m}^{3}\right)$ & 2671.20 & 5.62 & 2740.50 & 5.08 \\
\hline Toplam girdi & 47538.38 & 100.00 & 53978.98 & 100.00 \\
\hline Çıktı (verim) & 106464.00 & & 110280.00 & \\
\hline
\end{tabular}

(\%24) aldığını, bunu sırasıyla kimyasal gübrelerin (\%23) ve sulama suyunun (\%23) takip ettiğini belirlemișlerdir. Loghmanpour vd. (2013), İran'da turunçgil üretiminde enerji kullanımını incelemișler ve enerji girdileri içerisinde en ilk sırayı kimyasal gübrelerin (\%36.30), ikinci sırayı kimyasal ilaçların (\%33.62) aldığını belirlemișlerdir. Junior vd. (2014), Brezilya'da yaptıkları çalıșmada, turunçgil üretiminde enerji girdileri içerisinde yakıtın en yüksek payı (\%38.77) aldığını, bunu sırasıyla kimyasal ilaçlar (\%30.83) ve kimyasal gübrelerin (\%24.50) takip ettiğini belirlemișlerdir.

Mandarin üretiminin enerji analizi Çizelge 4'te verilmiștir. Mandarin üretiminden elde edilen enerji eșdeğerinin kullanılan enerji girdilerine oranlanması ile bulunan enerji çıktı/girdi oranı liyi Tarım Uygulamaları yapan ișletmelerde 2.24, İyi Tarım Uygulamaları yapmayan ișletmelerde 2.04 olarak bulunmuștur. Bu oran lyi Tarım Uygulamaları yapan ișletmelerde daha yüksek olup, İyi Tarım Uygulamaları yapmayan ișletmelerde girdilerin daha etkin kullanıldığını göstermektedir. Özkan vd. (2004), mandarin üretiminde enerji çıktı/girdi oranını 1.17, Pimentel (2009) 1.13, Namdari
Çizelge 4. Mandarin üretiminin enerji analizi

Table 4. Energy analysis of mandarin production

\begin{tabular}{lcc}
\hline & iTU yapan & iTU yapmayan \\
\hline Enerji girdileri (MJ ha $\left.{ }^{-1}\right)$ & 47538.38 & 53978.98 \\
Enerji çıktısı (MJ ha-1) & 106464.00 & 110280.00 \\
Enerji çıktı/girdi oranı & 2.24 & 2.04 \\
Enerji verimliliği (kg MJ-1) & 0.93 & 0.85 \\
Spesifik enerji (MJ kg-1) & 1.07 & 1.17 \\
Net enerji (MJ ha $\left.{ }^{-1}\right)$ & 58925.62 & 56301.02 \\
\hline
\end{tabular}

vd. (2011) 0.77 ve Loghmanpour vd. (2013) 1.72 olarak bulmușlardır. Çalıșmada elde edilen enerji çıtı/girdi oranının literatürdeki çalıșma sonuçlarından daha yüksek çımması, girdilerin daha etkin bir șekilde kullanıldığını göstermektedir.

Mandarin üretiminde enerji verimliliği İyi Tarım Uygulamaları yapan ișletmelerde $0.93 \mathrm{~kg} \mathrm{MJ}^{-1}$ İyi Tarım Uygulamaları yapmayan ișletmelerde ise $0.85 \mathrm{~kg} \mathrm{MJ}^{-1}$ olarak belirlenmiștir. Enerji verimliliği enerji kullanımı bașına alınan ürün miktarını ifade etmekte olup, bu değer İyi Tarım Uygulamaları yapan ișletmelerde dahayüksek bulunmuștur. Ürün 
Çizelge 5. Mandarin üretiminde kullanılan girdilerin enerji kaynaklarına göre dağıımı

Table 5. Distribution of the inputs according to energy sources in mandarin production

\begin{tabular}{lcccc}
\hline & \multicolumn{2}{c}{ iTU yapan } & \multicolumn{2}{c}{ iTU yapmayan } \\
\cline { 2 - 5 } & MJ ha' $^{-1}$ & $\%$ & MJ ha $^{-1}$ & 21.98 \\
\hline Doğrudan enerji & 11524.40 & 24.24 & 11865.72 & 78.02 \\
Dolaylı enerji & 36013.98 & 75.76 & 42113.26 & 100.00 \\
Toplam & 47538.38 & 100.00 & 53978.98 & 9.62 \\
Yenilenebilir enerji & 5173.94 & 10.88 & 5194.02 & 90.38 \\
Yenilenemeyen enerji & 42364.44 & 89.12 & 48784.96 & 100.00 \\
Toplam & 47538.38 & 100.00 & 53978.98 & \\
\hline
\end{tabular}

bașına kullanılan enerji miktarını ifade eden spesifik enerji liyi Tarım Uygulamaları yapan ișletmelerde $1.07 \mathrm{MJ} \mathrm{kg}{ }^{-1}$, İyi Tarım Uygulamaları yapmayan ișletmelerde 1.17 MJ kg-1 olarak bulunmuștur. Bu sonuca göre, İyi Tarım Uygulamaları yapan ișletmelerde bir kg mandarin üretmek için gerekli enerji miktarı 1.07 MJ olup, İyi Tarım Uygulamaları yapmayan ișletmelere göre daha avantajlı görülmektedir. Enerji çıktısı ve enerji girdileri arasındaki farkı ifade eden net enerji, lyi Tarım Uygulamaları yapan ișletmelerde 58925.62 MJ ha 1, İyi Tarım Uygulamaları yapmayan ișletmelerde ise $56301.02 \mathrm{MJ}$ ha-1 olarak bulunmuștur. Enerji analizi sonuçlarına göre, mandarin yetiștiriciliğinin İyi Tarım Uygulamaları yapan ișletmelerde daha avantajlı olduğu belirlenmiștir.

Mandarin üretiminde kullanılan girdilerin enerji kaynaklarına göre dağılımı Çizelge 5'te verilmiștir.

İyi Tarım Uygulamaları yapan ișletmelerde doğrudan enerjinin toplam enerji girdileri içindeki payı \%24.24, dolaylı enerjinin payı \%75.76 olarak bulunurken, bu oranlar İyi Tarım Uygulamaları yapmayan ișletmelerde sırasıyla \%21.98 ve \%78.02 olarak belirlenmiștir. Dolaylı enerji kaynakları çoğunlukla kimyasal gübreler ve ilaçlardan olușmakta olup, İyi Tarım Uygulamalarında gübre ve ilaç kullanımı kontrollü olarak yapııdığı için, dolaylı enerjinin toplam enerji içindeki payı lyi Tarım Uygulamaları yapan ișletmelerde daha düșüktür. Bilinçsiz ilaç ve gübre kullanımı hem girdilerin kaybına hem de çevrenin olumsuz yönden etkilenmesine neden olmaktadır.

İyi Tarım Uygulamaları yapan ișletmelerde yenilenebilir enerji kaynaklarının toplam enerji girdileri içindeki payı \% 10.88, İyi Tarım Uygulamaları yapmayan ișletmelerde \%9.62 olarak bulunmuștur. Yenilenemeyen enerji kaynaklarının payı İyi Tarım Uygulamaları yapan ișletmelerde \%89. 12, İyi Tarım
Uygulamaları yapmayan ișletmelerde \%90.38 olarak bulunmuștur. Yenilenemeyen enerji kaynakları sınırlı ve çevreye zarar verici özellikte olduğundan dolayı, İyi Tarım Uygulamaları yapan ișletmelerde bu oranın az da olsa daha düșük çıkması bir avantaj olarak değerlendirilebilir.

Namdari vd. (2011), mandarin üretiminde doğrudan enerjinin payını \%58.82, dolaylı enerjinin payını \%41.18, yenilebilir enerjinin payını \%34.43, yenilenemeyen enerjinin payını \%65.57 olarak belirlemișlerdir. Loghmanpour vd. (2013), İran'da turunçgil üretiminde doğrudan enerjinin payını \%12, dolaylı enerjinin payını \%88, yenilenebilir enerjinin payını \%10, yenilenemeyen enerjinin payını \% 90 olarak bulmușlardır. Araștırma sonucunda elde edilen sonuç Loghmanpour vd. (2013) tarafından elde edilen araștırma sonucuyla benzerlik göstermektedir.

\section{Mandarin Üretiminin Ekonomik Analizi}

Mandarin üretiminde üretim masrafları Çizelge 6'da verilmiștir. İyi Tarım Uygulamaları yapan ișletmelerde toplam üretim masrafları 22924.96 TL ha-1 olarak bulunmuș olup, bunun \%54.13'ünü değișken masraflar, \%45.87'sini sabit masraflar olușturmaktadır. Değișken masraf kalemleri içinde yer alan ișçilik masraflarının toplam üretim masraflarının içindeki payı \%21.83, gübre masraflarının payı \%12.21, ekipman masraflarının payı \%6.46, ilaç masraflarının payı \%4.47, su ve elektrik masraflarının payı \%4.19 olarak bulunmuștur. Sertifikasyon ücreti ve analiz ücreti lyi Tarım Uygulamaları yapan ișletmelerde değișken masraflar içinde yer almakta olup, bu ücretlerin üretim masrafları içindeki payı sırasıyla $\% 0.97$ ve \%0.46 olarak bulunmuștur. Üretim masrafları içerisinde en yüksek payı sabit masraflar içerisinde yer alan çıplak arazi değeri faizi (\%32.61) olușturmaktadır. 
Çizelge 6. Mandarin üretiminde üretim masrafları

Table 6. Production expenses in mandarin production

\begin{tabular}{lcccc}
\hline \multirow{2}{*}{ Masraflar } & \multicolumn{2}{c}{ iTU yapan } & \multicolumn{2}{c}{ iTU yapmayan } \\
\cline { 2 - 5 } & TL ha' & $\%$ & 5042.50 & 23.28 \\
\hline Ișçilik masrafları & 5005.00 & 21.83 & 1500.00 & 6.92 \\
Ekipman masrafları & 1480.00 & 6.46 & 2550.00 & 11.77 \\
Gübre masrafları & 2800.00 & 12.21 & 1165.00 & 5.38 \\
Illaç masrafları & 1025.00 & 4.47 & 931.00 & 4.30 \\
Su ve elektrik masrafları & 960.00 & 4.19 & 0.00 & 0.00 \\
Sertifikasyon ücreti & 223.00 & 0.97 & 0.00 & 0.00 \\
Analiz ücreti & 104.00 & 0.46 & 783.20 & 3.62 \\
Döner sermaye faizi & 811.80 & 3.54 & $\mathbf{1 1 9 7 1 . 7 0}$ & $\mathbf{5 5 . 2 7}$ \\
Değișken masraflar & $\mathbf{1 2 4 0 8 . 8 0}$ & $\mathbf{5 4 . 1 3}$ & 359.15 & 1.66 \\
Genel idari giderler & 372.26 & 1.62 & 7200.00 & 33.24 \\
Cıplak arazi değeri faizi & $\mathbf{7 4 7 5 . 0 0}$ & 32.61 & 340.50 & 1.57 \\
Sulama alet-makine amortismanı & 353.30 & 1.54 & 170.20 & 0.78 \\
Sulama alet-makine faizi & 176.70 & 0.77 & 1079.90 & 4.99 \\
Tesis masrafları amortisman payı & 1579.00 & 6.89 & 540.00 & 2.49 \\
Tesis masrafları faizi & 559.90 & 2.44 & $\mathbf{9 6 8 9 . 7 5}$ & 44.73 \\
Sabit masraflar & $\mathbf{1 0 5 1 6 . 1 6}$ & 45.87 & $\mathbf{2 1 6 6 1 . 4 5}$ & $\mathbf{1 0 0 . 0 0}$ \\
Üretim masrafları & $\mathbf{2 2 9 2 4 . 9 6}$ & 100.00 & &
\end{tabular}

İyi Tarım Uygulamaları yapmayan ișletmelerde toplam üretim masrafları $21661.45 \mathrm{TL}^{\mathrm{ha}}{ }^{-1}$ olarak bulunmuștur. Masraflar içinde en yüksek payı, İyi Tarım Uygulamaları yapmayan ișletmelerde olduğu gibi çıplak arazi değeri faizi (\%33.24) olușturmaktadır. İșçilik masraflarının üretim masrafları içindeki payı \%23.28, gübre masraflarının payı \%11.77, ekipman masraflarının payı \%6.92, ilaç masraflarının payı \%5.38, su ve elektrik masraflarının payı \%4.30 olarak belirlenmiștir.

İyi Tarım Uygulamaları yapan ve yapmayan ișletmelerde mandarin üretiminin ekonomik analizi Çizelge 7'de verilmiștir. lyi Tarım Uygulamaları yapan ișletmelerde $1 \mathrm{~kg}$ mandarin yetiștirmenin maliyeti $0.52 \mathrm{TL}$ olarak bulunmuștur. Ortalama verim 44360 kg ha $^{-1}$, gayri safi üretim değeri ise $28390.40 \mathrm{TL}$

Çizelge 7. Mandarin üretiminin ekonomik analizi

Table 7. Economic analysis of mandarin production

\begin{tabular}{|c|c|c|}
\hline & ITU yapan & ITU yapmayan \\
\hline Verim (kg ha $\left.{ }^{-1}\right)$ & 44360.00 & 45950.00 \\
\hline Gayri safi üretim değeri (TL ha-1) & 28390.40 & 25732.00 \\
\hline Değișken masraflar (TL ha-1) & 12408.80 & 11971.70 \\
\hline Sabit masraflar (TL ha-1) & 10516.16 & 9689.75 \\
\hline Üretim masrafları (TL ha-1) & 22924.96 & 21661.45 \\
\hline Birim maliyet (TL kg-1) & 0.52 & 0.47 \\
\hline Brüt kâr (TL ha-1) & 15981.60 & 13760.30 \\
\hline Mutlak kâr (TL ha') & 5465.44 & 4070.55 \\
\hline Nispi kâr & 1.24 & 1.19 \\
\hline
\end{tabular}


ha-1 olarak belirlenmiștir. Gayri safi üretim değerinden değișken masrafların çıkartılmasıyla elde edilen brüt kâr 15981.60 TL ha'-1, üretim masraflarının çıkartılmasıyla elde edilen net kâr 5465.44 TL ha ${ }^{-1}$ nispi kâr ise 1.24 olarak bulunmustur.

Iyi Tarım Uygulamaları yapan ișletmelerde $1 \mathrm{~kg}$ mandarin yetiștirmenin maliyeti $0.47 \mathrm{TL}$ olarak bulunmuștur. Ortalama verim 45950 kg ha-1, gayri safi üretim değeri $25732 \mathrm{TL} \mathrm{ha}^{-1}$, brüt kâr 13760.30 TL ha-1, net kâr 4070.55 TL ha-1, nispi kâr ise 1.19 olarak hesaplanmıștır.

Aydın Can ve Yercan (2006), İzmir ilinde yürüttükleri çalıșmada, mandarin üretiminde nispi kârı 1.34 olarak belirlemișlerdir. Araștırma sonucunda elde edilen sonuç, Aydın Can ve Yercan (2006) tarafindan elde edilen sonuçla benzerlik göstermektedir.

Her iki üretim tarzında da mandarin yetiștiriciliği kârlı olmakla birlikte, İyi Tarım Uygulamaları yapan ișletmelerde mandarin yetiștiriciliği daha kârlı görülmektedir. İyi Tarım Uygulamaları yapan ișletmelerden beklenen özellikle kimyasal gübre, ilaç ve akaryakıt kullanımında daha kontrollü girdi kullanımı olmasıdır, ancak bu çalıșmada bunu net bir șekilde görememekteyiz. Bu sonucun ana nedeni olarak ülkemizde İyi Tarım Uygulamalarına yönelik üretimin yeni bașlamıș olması ve üreticilerin geçmișteki alıșkanlıklarından çok çabuk kurtulamamaları gösterilebilir. Önümüzdeki süreçte daha etkin bir izleme ve değerlendirme yapılacağı öngörüsü ile girdi kullanımında etkinliğin artacağı söylenebilir. Bu durum üretim maliyetlerinin İyi Tarım Uygulamaları yönünde pozitif olarak değișeceği ve maliyetlerle birlikte kullanılan girdilerin olumsuz çevresel etkilerini de azaltacaktır.

\section{Sonuçlar}

Bu çalıșma ile İzmir ilinde lyji Tarım Uygulamaları yapan ve yapmayan ișletmelerde mandarin üretiminde karșılaștırmalı enerji analizi ve ekonomik analiz yapılmıștır. İyi Tarım Uygulamaları yapan ișletmelerde enerji çıktı/girdi oranı 2.24, lyi Tarım Uygulamaları yapmayan ișletmelerde ise 2.04 olarak bulunmuștur. Bu sonuç, İyi Tarım Uygulamaları yapan ișletmelerde üretim girdilerinin daha kontrollü kullanıldığının bir göstergesi olarak belirtilebilir. Özellikle İyi Tarım Uygulamaları yapmayan üreticilerin girdi kullanımı bakımından yayım elemanları tarafından eğitilmeleri önerilmektedir. Ekonomik analiz sonucunca göre ise, l̇yi Tarım Uygulamaları yapan ișletmelerde nispi kâr 1.24, İyi Tarım Uygulamaları yapmayan ișletmelerde ise 1. 19 olarak hesaplanmıș olup, mandarin yetiștiriciliği liyi Tarım Uygulamaları yapan ișletmelerde daha kârlı görülmektedir. Bu bağlamda, iyi tarım ürünlerine pazar ayrıcalığı getirilmesi için çalıșmalar yürütülmesinde yarar öngörülmektedir. İyi tarım ile üretilen ürünlerin biraz daha yüksek fiyatla satılabilmesini sağlayan yaptırımların uygulamaya alınması sağlanmalıdır.

Bu sonuçlar dikkate alınarak, İyi Tarım Uygulamaları́nın yaygınlaștırılması oldukça önem tașımaktadır. lyi Tarım Uygulamalarının yaygınlaștırılması için; en bașta lyi Tarım Uygulamaları yapan üreticilere teșvik amaçlı desteklerin artırılması ve iyi tarım ürünlerine alım garantisi getirilmesinin yararlı olacağı düșünülmektedir. Bunların yanında, bu alandaki üretici eğitimlerinin etkin șekilde sürdürülmesi önemli görülmektedir. Eğitimlerin süreklilik arz etmesi ve tarım danıșmanlarının eğitimlere doğrudan dâhil edilmesi yönünde yönetmelik değișiklikleri vb. uygulamalar gündeme alınabilir. Üreticiler tarafından gündeme getirilen bunların dıșındaki talep ve önermelerin ise, lyi Tarım Uygulamaları'nda yönetmelik ve yönergeler kapsamında olması veya yapılması gereken teknik uygulamalar olarak değerlendirilmesi daha doğru bir yaklașımdır.

\section{Teșekkür}

Bu çalıșma, TAGEM desteğiyle yürütülen "İzmir ve Manisa İlerinde Üreticilerin İyi Tarım Uygulamalarına Yaklașımı ve Uygulamaların Ekonomik Analizi" bașlıklı projeden elde edilen verilerden yararlanılarak hazırlanmıștır.

\section{KAYNAKLAR}

Açıl AF, Demirci R (1984). Tarım Ekonomisi Dersleri. Ankara Üniversitesi Ziraat Fakültesi Yayınları No. 880, Ankara.

Anonim (2017a). http://www.zmo.org.tr/genel/bizden_ detay.php?kod=23137 (Erișim tarihi, 12.06.2017).

Anonim (2017b). belgelendirme.ctr.com.tr/iyi-tarimuygulamalari-nedir.html (Erișim tarihi, 12.06.2017).

Aydın Can B, Yercan M (2006). İzmir ili Seferihisar ilçesinde mandarin üretiminin ekonomik analizi. Ege Üniversitesi Ziraat Fakültesi Dergisi, 43(1):133-144.

Aygören E (2016). Turunçgiller Durum/Tahmin 2015/2016. TEPGE Yayın No: 282, ISBN:978-605-9175-692. Tarımsal Ekonomi ve Politika Geliștirme Enstitüsü, Ankara. 
Baran MF, Oğuz Hi, Gökdoğan O (2016). Determining the energy usage efficiency of walnut (Juglans Regia L.) cultivation in Turkey. Erwerbs-Obstbau, 59(1):77-82, DOI: 10.1007/s10341-016-0301-y.

Baran MF, Oğuz Hí, Gökdogan O (2017). Determination of energy input-output analysis in organic strawberry production. Fresenius Environmental Bulletin, 26(3): 20762081.

Bilgili ME (2012). Limon üretiminde enerji kullanım etkinliğinin belirlenmesi: Adana ili örneği. Tarım Makinaları Bilimi Dergisi, 8(2): 199-203.

De D, Singh S, Chandra H (2001). Technological impact on energy consumption in rain fed soybean cultivation in Madhya Pradesh. Applied Energy, 70: 193-213.

Junior NC, Milan M, Romanelli TL (2014). Energy demand in citrus production under varied operational efficiency values. Engenharia Agricola, Jaboticabal, 34(4): 746-754.

Kıral T, Kasnakoğlu H, Tatıdil FF, Fidan H, Gündoğmuș E (1999). Tarımsal Ürünler İçin Maliyet Hesaplama Metodolojisi ve Veri Tabanı Rehberi. Proje Raporu 1999-13, Yayın No:37, Ankara.

Loghmanpor Zarini R, Tabatabaekoloor R, Akram A (2013). Energy use in citrus production of Mazandaran province of Iran. African Crop Science Journal, 21 (1): 61-65.

Mandal KG, Saha KP, Gosh PL, Hati KM, Bandyopadhyay KK (2002). Bioenergy and economic analyses of soybean based crop production systems in central India. Biomass \& Bioenergy, 23: 337- 345.

Mohammadi A, Rafiee S, Mohtasebi SS, Rafiee H (2010). Energy inputs-yield relationship and cost analysis of kiwifruit production in Iran. Renewable Energy, 35: 1071-1075.

Namdari M, Kangarshahi AA, Amiri NA (2011). Inputouput energy analysis of citrus production in Mazandaran province of Iran. African Journal of Agricultural Research, 6(1 1): 2558-2564

Özkan B, Akçaöz H, Karadeniz F (2004). Energy requirement and economic analysis of citrus production in Turkey. Energy Conversion and Management, 45: 18211830.
Öztürk HH (2011). Bitkisel üretimde enerji yönetimi. Hasad Yayıncilık. Ankara. 2565. ISBN:978-975-837778-7.

Pimentel D (2009). Energy inputs in food crop production in developing and developed nations. Energies, 2(1): 1-24.

Rafiee S, Seyed H, Mousavi A, Ali M (2010). Modeling and sensivity analysis of energy inputs for apple production in Iran. Energy, 35: 3301-3306.

Singh JM (2002). On farm energy use pattern in different cropping systems in Haryana, India. International Institute of Management University of Flensburg. Sustainable Energy Systems and Management. Master of Science, Germany.

Strapatsa AV, Nanos GD, Tsatsarelis CA (2006). Energy flow for integrated apple production in Greece. Agricultural Ecosystem and Environment, 116: 176-180.

Tanrıvermiș H (2000). Orta Sakarya Havzası'nda Domates Üretiminde Tarımsal İlaç Kullanımının Ekonomik Analizi. Ankara Üniversitesi Araștırma Enstitüsü, Yayın No:42, Ankara.

Yaldız O, Öztürk HH, Zeren Y, Bașçetinçelik A (1993). Energy usage in production of field crops in Turkey. 5th International Congress on Mechanization and Energy in Agriculture. Kușadası, 11-14 Ekim, s: 527-536.

Yılmaz I, Akcaöz H, Özkan B (2005) An analysis of energy use and input costs for cotton production in Turkey. Renewable Energy, 30: 145-155.

Yılmaz I, Özalp A, Aydoğmuș F (2010). Antalya ili bodur elma üretiminde enerji kullanım etkinliğinin belirlenmesi: Elmalı ilçesi örneği. Akdeniz Üniversitesi Ziraat Fakültesi Dergisi, 23(2): 93-97.

Wang O, Zhang E, Li F, Li F (2008). Runoff Efficiency and the Tecnique of Micro-water Harvesting with Ridges and Furrows, for Potato Production in Semi-arid Areas. Water Resor Manage, 22: 1431-1443.

Yıldırım, O., Halloran N., Çavușoğlu, Ș., Șengül, N. (2009). Effects of Different Irrigation Programs on the Growth, Yield and Fruit Quality of Drip-irrigated Melon. Turkish Journal of Agriculture and Forestry, 33: 243-255. 